ECONOMIC GROWTH CENTER

YALE UNIVERSITY

P.O. Box 208629

New Haven, CT 06520-8269

http://www.econ.yale.edu/ egcenter/

CENTER DISCUSSION PAPER NO. 939

\title{
Household Decision Making and Savings Impacts: Further Evidence from a Commitment Savings Product in the Philippines
}

\author{
Nava Ashraf \\ Harvard Business School \\ Dean Karlan \\ Yale University \\ Wesley Yin \\ University of Chicago
}

June 2006

Notes: Center Discussion Papers are preliminary materials circulated to stimulate discussions and critical comments.

We thank the Green Bank of Caraga for cooperation throughout this experiment, John Owens and the USAID/Philippines Microenterprise Access to Banking Services Program team for helping to get the project started, Chona Echavez for collaborating on the field work, Larry Katz, Sendhil Mullainathan and Chris Udry for comments, and Nathalie Gons, Tomoko Harigaya, Karen Lyons and Lauren Smith for excellent research and field assistance. We thank the National Science Foundation (SGER SES-0313877), Innovations for Poverty Action, Russell Sage Foundation and the Social Science Research Council for funding. All views, opinions and errors are our own.

This paper can be downloaded without charge from the Social Science Research Network electronic library at: $\underline{\text { http://ssrn.com/abstract }=912771}$

An index to papers in the Economic Growth Center Discussion Paper Series is located at: http://www.econ.yale.edu/ egcenter/research.htm 


\title{
Household Decision Making and Savings Impacts: Further Evidence from a Commitment Savings Product in the Philippines
}

\author{
Nava Ashraf \\ Harvard Business School \\ nashraf@hbs.edu
}

\author{
Dean Karlan \\ Yale University \\ dean.karlan@yale.edu
}

\author{
Wesley Yin \\ University of Chicago \\ wyin@uchicago.edu
}

\begin{abstract}
Commitment devices for savings could benefit those with self-control as well as familial or spousal control issues. We find evidence to support both motivations. We examine the impact of a commitment savings product in the Philippines on household decision making power and selfperception of savings behavior, as well as actual savings. The product leads to more decision making power in the household for women, and likewise more purchases of female-oriented durable goods. We also find that the product leads women who appear time-inconsistent in a baseline survey to self-report being a disciplined saver in the follow-up survey. For impact on savings balances, we find that the $81 \%$ increase in savings after one year did not crowd out savings held outside of the participating bank, but that the longer-term impact over two and a half years on bank savings dissipated to only a 33\% increase, which is no longer statistically significant. We discuss reasons why the effect dissipated and the implications for designing and implementing sustainable, equilibrium-shifting interventions.
\end{abstract}

JEL Codes: D12, D63, D91, J16, O12, O16

Keywords: Savings, microfinance, female empowerment, household decision making, commitment 


\section{Introduction}

Commitment devices for savings could benefit those with self-control as well as familial or spousal control issues. The literature on household savings, and on informal savings devices in particular, has focused on separating self-control motivations and impacts from spousal or familial-control explanations (Anderson and Baland 2002; Gugerty 2006). A simple reason may exist why this task has proven difficult: such devices can serve both purposes. We examine the impact of a commitment savings product in the Philippines on household decision making power and self-perception of savings behavior, and indeed find evidence for both.

We designed and implemented a commitment savings product with the Green Bank of Caraga, a rural bank in the Philippines. The savings product provided individuals with a commitment to restrict access to their savings, thus potentially helping with either self-control or family-control issues. Each individual defined either a "date” goal or an "amount” goal, and was then not able to withdraw their funds until the goal was reached. We reported earlier (Ashraf, Karlan and Yin 2006) that after one year individuals who were offered the product increased their savings by $81 \%$ relative to a control group, and that in accordance with the theoretical literature on hyperbolic preferences (Laibson 1997; O'Donoghue and Rabin 1999) and dual-self models (Gul and Pesendorfer 2001; 2004; Fudenberg and Levine 2005), time-inconsistent individuals were the ones most likely to demonstrate a preference for commitment.

We examine three questions: (1) did offering the commitment savings product change the household decision making power and self-perception of savings behaviors after one year; (2) did the increase in savings crowd out other household savings after one year; and (3) did the impact on savings held at the Green Bank sustain itself in the long term, that is, after two and a half years? This paper uses two new sources of data: a follow-up survey conducted on $92 \%$ of those surveyed in the baseline one year later, and administrative bank data collected after two and a half years. 
A growing literature on intra-household bargaining finds that exogenous increases in female share of income, interpreted as providing the female more power within the household, lead to an allocation of resources that better reflect preferences of the woman (Duflo 2003; Rangel 2005). This often leads to greater investment in education, housing, and nutrition for children (Thomas 1990; 1994; 1995; Duflo 2003). For these reasons and others, many development interventions focus on increasing the power of women in the household. ${ }^{1}$ However, there is little rigorous evidence that interventions that focus on power directly (rather than through increasing income) actually can promote female empowerment, nor have we assessed the consequences of such induced (rather than "naturally” encountered) empowerment.

We contribute to this literature by exogenously increasing control of a financial asset. Some current bank clients are randomly chosen to receive an offer to open an additional "commitment" account in their own name. We then examine the impact on both self-reported decision making processes within the household and the subsequent household allocation of resources. The commitment savings product caused an increase in household decision making power for married women, measured both in the women's own reporting of how household decisions were made and in the household's purchases of goods typically used by women. Notably, the effect on decision making power is strongest for married women who had below-median household decision making power prior to the intervention. The effect is found for three categories of decisions: expenditures on personal items, recreational and expensive items and number of children. We also find that households that were offered SEED were more likely to buy durables typically used by women within the household. We find no such effects on household durables when a man was offered the SEED commitment savings account.

However, we also find an impact on self-perception of savings behavior. Note that in earlier work we found that time-inconsistent women (as measured through time preference questions in a

\footnotetext{
${ }^{1}$ See, for example, (World Bank 2001). By "female empowerment" we mean increasing the bargaining power of the woman within the household, manifested through increased influence in household decisions and through household outcomes that greater reflect her preferences.
} 
baseline survey) were more likely to open the SEED account than time consistent women. Here we find that for time-inconsistent women, the SEED account made them more likely to perceive themselves as a disciplined saver and to report saving available cash rather than spending it. Thus, evidence exists to show that the commitment device had an impact on both spousal control and (at least the self-perception of) self-control.

We also examine whether the increase in savings merely crowded out savings held elsewhere. The literature on savings over the life-cycle repeatedly points to the limited ability for deferred savings programs to increase aggregate savings (Feldstein 1974; 1982; 1996). However, it is not clear that deferred savings interventions should crowd out other savings when time-inconsistency or intra-household bargaining issues underpin the demand for illiquid deferred savings. Indeed, commitment savings devices are thought to increase savings for present-biased discounters (Laibson 1997). Benartzi and Thaler (2004) and Ashraf, Karlan and Yin (2006) provide evidence for positive savings response to commitment savings devices. The latter study shows that institutional savings increase in response to a randomized offering of a commitment savings account. However, neither study is able to assess whether savings increases are accompanied by contemporaneous crowd-out of savings held in physical assets, savings at other formal or informal institutions, or accompanied by negative savings as represented by increased debt. Similar crowd-out questions remain unanswered in other interventions which increase savings held in specific accounts (Duflo, Gale, Liebman, Orszag and Saez 2006).

We find that increases in institutional savings resulting from the commitment product offering do not crowd out other savings. We find positive yet insignificant treatment effects on savings held in physical assets, in formal savings at other institutions, and in informal savings vehicles. Further, clients randomly assigned to the commitment-treatment group are no more likely to have borrowed money in the past year than the control group, nor is their average level of debt significantly different than that of the control clients. 
Lastly, we find that the one-year impact reported in Ashraf, Karlan and Yin (2006) was not sustained after two and a half years. Savings impact for the treatment clients is still positive, but smaller in magnitude and statistically insignificant. We posit several reasons for the diminished impact of the commitment product. First, while use of the commitment account was heterogeneous in intensity, even for high-use individuals the account was not used repeatedly beyond the first year, despite its effectiveness at increasing savings for these clients. Perhaps the account does indeed work but requires a proactive bank to help set the goal and establish the account (again) as a mechanism to help achieve that goal. Similarly, the theory behind the preference for commitment suggests that the commitment account may have caused a deviation from a low-savings equilibrium; gradually individuals return to the equilibrium they were in before. Bernheim, Ray and Yeltekin (1999) describe how a low asset trap can be exacerbated through self-control problems, but that self-control can be more easily imposed once a certain threshold level of assets is crossed. If sustained interventions are necessary to help clients reach a new equilibrium, this may be an argument for greater proactivity on the bank’s side. However, given that these are small depositors, such proactivity would likely not be profitable for the bank and may need to be subsidized, similar to the interventions discussed by (Kremer and Miguel 2004). We discuss the implications of this in more detail later.

This paper proceeds as follows. Section II describes the commitment savings product and the experimental design. Section III presents the empirical results on household decision making and self-perception of savings behavior. Section IV presents the empirical results on crowd-out of other savings. Section V presents the empirical results for estimating the long-term impact of the commitment product on financial institutional savings. Section VI concludes. 


\section{Intervention and Experimental Design}

\section{The SEED Account}

We designed and implemented a commitment savings product called a SEED (Save, Earn, Enjoy Deposits) account with the Green Bank of Caraga, a small rural bank in Mindanao, Philippines. The SEED account requires that clients commit not to withdraw funds that are in the account until they reach a goal date or amount but does not explicitly commit the client to deposit funds after opening the account. The SEED accounts are individual accounts, even if the participants were married. There are three critical design features, one regarding withdrawals and two regarding deposits. First, individuals restricted their rights to withdraw funds until they reached a specific goal. Clients could restrict withdrawals until a specified month when large expenditures were expected, e.g. the beginning of school, Christmas, a particular celebration, or when business needs arose. Alternatively, clients could set a goal amount and only have access to the funds once that goal was reached (e.g., saving a quantity of money known to be needed for a new roof). The clients had complete flexibility to choose which of these restrictions they would like on their account. Once the client had made the decision they could neither change it, nor could they withdraw from the account until they met their chosen goal amount or date. ${ }^{2}$ After the goal is reached, the SEED client, not his or her spouse, could withdraw the funds. All clients, regardless of the type of restriction they chose, were encouraged to set a specific savings goal as the purpose of their SEED savings account. SEED marketers insisted that the client herself or himself, and not another household member, set the goal. ${ }^{3}$

\footnotetext{
${ }^{2}$ Exceptions are allowed for medical emergency, in which case a hospital bill is required, for death in the family, requiring a death certificate, or relocating outside the bank's geographic area, requiring documentation from the area government official. The clients who signed up for the SEED product signed a contract with the bank agreeing to these strict requirements. After six months of the project, no instances occurred of someone exercising these options. For the amount-based goals, the money remains in the account until either the goal is reached or the funds withdrawn or the funds are requested under an emergency.

${ }^{3}$ SEED marketers reported instances of household visits in which the husband tried to influence the goalsetting process. Typically the marketers then asked that only the wife to give her goal and this was recorded, but at no point did the marketer make an issue out of the goal setting process. Green Bank
} 
The savings goal was written on the SEED form used to open the account, as well as on a "Commitment Savings Certificate" that was given to the client to keep. Forty-eight percent of clients reported wanting to save for a celebration, such as Christmas, birthday or fiesta. ${ }^{4}$ Twentyone percent of clients chose to save for tuition and education expenses, while 20 percent of clients chose business and home investments as their specific goals.

The bank offered each client a locked box (called a "ganansiya" box) for a small fee in order to encourage deposits. This locked box is similar to a piggy bank: it has a small opening to deposit money and a lock to prevent the client from opening it. In our setup, only the bank, and not the client, had a key to open the lock. Thus, in order to make a deposit, clients need to bring the box to the bank periodically. Out of the 202 clients who opened accounts, 167 opted for this box. This feature can be thought of as a mental account with a small, physical barrier; the box is a merely a mechanism that provides individuals a way to save their small change. Individuals put loose change or small bills on a daily basis, hence make "deposits" that normally would be too small to warrant a trip to the bank. These small daily "deposits” keep cash out of one's pocket and then eventually, once enough money accumulates in the box, the client deposits the funds at the bank. The barrier, however, is largely psychological; the box is easy to break and hence is a weak physical commitment at best. ${ }^{5}$

Other than providing a possible commitment savings device, no further benefit accrued to individuals with this account. The interest rate paid on the SEED account was identical to the interest paid on a normal savings account (4 percent per annum).

prohibits spouses from being able to withdraw from each others' accounts, unless the account was explicitly opened as a joint account. No SEED accounts were opened as joint accounts.

${ }^{4}$ Fiestas are large local celebrations that happen at different dates during the year for each barangay (smallest political unit \& defined community, on average containing 1000 individuals) in this region. Families are expected to host large parties, with substantial food, when it is their barangay's fiesta date. Families often pay for this annual party through loans from local high-interest-rate money-lenders.

${ }^{5}$ To facilitate deposits, clients also were offered automatic transfers from a primary checking or savings account into the SEED account. This feature was not popular. Many clients reported not using their checking or savings account regularly enough for this option to be meaningful. Even though preliminary focus groups indicated demand for this feature, only 2 out of the 202 clients opted for automated transfers. 


\section{The Experimental Design and Data Collection}

Our sample for the field experiment consists of 4001 adult Green Bank clients who have savings accounts in one of two bank branches in the greater Butuan City area, and who have identifiable addresses. We randomly chose 3154 out of 4001 bank clients to interview for our baseline survey. We then performed a second randomization to assign these individuals to three groups: commitment-treatment $(\mathrm{T})$, marketing-treatment $(\mathrm{M})$, and control $(\mathrm{C})$ groups. One-half the sample was randomly assigned to $\mathrm{T}$, and a quarter of the sample each were randomly assigned to groups $\mathrm{M}$ and $\mathrm{C}$. We verified at the time of the randomization that the three groups were not statistically different in terms of preexisting financial and demographic data. Of the 3154, 1777 were located by the survey team and then completed a survey. See Ashraf, Karlan and Yin (2006) for analysis that shows that the treatment and control groups were observably statistically similar at the time of the baseline.

Next, we trained a team of marketers hired by the partnering bank to go to the homes and/or businesses of the clients in the commitment-treatment group, to stress the importance of savings to them - a process which included eliciting the clients' motivations for savings and emphasizing to the client that even small amounts of saving make a difference - and then to offer them the SEED product. We were concerned, however, that this special (and unusual) face-to-face visit might in and of itself inspire higher savings. To address this concern, we created a second treatment, the "marketing” treatment. We used the same exact script for both the commitmenttreatment group and the marketing-treatment group, up to the point when the client was offered the SEED savings account. For instance, members of both groups were asked to set specific savings goals for themselves, write those savings goals into a specific "encouragement” savings certificate, and talk with the marketers about how to reach those goals. However, members of the marketing-treatment group were neither offered nor allowed to open the SEED account. Bank staff were trained to refuse SEED accounts to members of the marketing-treatment and control groups, and to offer a "lottery” explanation: clients were chosen at random through a lottery for a 
special trial period of the product, after which time it would be available for all bank clients. Green Bank reported that this happened on fewer than ten occurrences. ${ }^{6}$

After one year, we conducted a follow-up survey on each of the participants. The tracking rate was high: $92 \%$ of those in the baseline were tracked and agreed to a second survey. Those in the treatment group were equally likely to complete a follow-up survey as those in the marketing or control group. This survey contained three sections: (1) inventory of assets, in order to measure whether the impact on savings represented a net increase in savings or merely a crowdout of other assets; (2) impact on household decision making and savings attitudes; and (3) impact on economic decisions, such as purchase of durable goods, health and consumption.

\section{Impact on Household Decision Making and Self-Perception of Savings Behavior}

\section{Household Decision Making Power}

We first examine whether being offered the SEED account changed the decision making roles in the household. In the follow-up survey, we ask questions regarding family planning, financial and consumption decisions in order to ascertain the structure of spousal or familial control within married households. For each decision category, we record whether the principle decision-maker is the respondent, the spouse, or both. Responses are assigned values of two, zero and one, respectively.

Table 2, Panel A, shows the impact of treatment assignment on household decision making for married women. ${ }^{7}$ The outcome variable is a decision making index calculated as the average of responses across nine decision categories. We find that assignment to the treatment group leads to a 0.051 point increase in the decision making index (Table 2 Column 1). The effect

\footnotetext{
${ }^{6}$ In only one instance an individual in the control group opened a SEED account. This individual is a family member of the owners of the bank and hence was erroneously included in the sample frame. Due to the family relationship, the individual was dropped from all analysis.

${ }^{7}$ This applies to married women whose spouses live at home with them. 53 out of 696 married women had no spouse in the house in both baseline and follow-up; 24 out of 541 married men had no spouse during both surveys. These married individuals were not included in our analysis, as their spouses were not sufficiently present in the household to have influence in decision making.
} 
suggests that on average one out of twenty women assigned to the treatment group reported an increase in their decision making role in one decision category. The average effect masks heterogeneous treatment effects across married women. Next, we separately analyze the impact on women who began the year below (above) the median decision making power. We find that the average effect is entirely driven by increases in decision making ability for women who were below the baseline median (comparing columns 2 and 3)—a fact consistent with initially lessempowered women gaining decision making ability through increased financial savings and control over committed assets. The impact for women below the baseline median is double the average effect, indicating that on average one out of 10 married women in the treatment group report greater decision making ability in one category. In contrast, we find no such treatment effect for married men (Table 2, Panel B).

Table 3 reports the impact for married women on household decision making for each of the nine decision categories comprising the index used in Table 2. Panel A shows the results for the full sample. We find impact on two decisions: expensive purchases and number of children. For women below the median in terms of household decision making power (Panel B), we find a significant impact of treatment assignment regarding purchases of expensive items, decisions to assist family members and purchases of items for personal use. For women above the baseline median (Panel C), the only categories with significant treatment impacts are schooling for children and number of children.

Next, we examine whether the increased reported decision making led to a difference in the types of goods purchased for the household. By increasing the assets available for lumpy purchases, the mere presence of the SEED account may increase female decision-making power in the household and hence increase the likelihood that the household acquires female-oriented durables. Naturally, if the account is held in the women's name this effect should be even stronger. 
We use three categories for expenditures: house repair, female-oriented durables (washing machines, sewing machines, electric irons, kitchen appliances, air-conditioning units, fans, stoves, etc.), and other durables (vehicles, entertainment and recreational goods). Table 4 finds no significant impacts on the choice and/or quantity of durables purchased in the household in aggregate, nor broken down by gender. Table 5 analyzes the same dependent variables, but separately for those above and below the median in terms of household decision making power at the baseline (similar to Table 3 Panel B and Panel C when analyzing the impact on decisionmaking power). We find that both the number of items purchased and the total expenditures of consumer durables traditionally associated with female use in the Philippines increase for married women who were below the median in pre-existing bargaining power. This effect is smaller, and not statistically significant, for married women above the median. This finding is consistent with the impact on decision making ability for purchases of personal items and durable goods. We do not, however, find that married households where the women are below the median in decision making ability increase expenditures on other non-female specific durables. Likewise, we do not find any effect for men offered SEED, either in aggregate or for those above or below the median in household decision making power (Table 5, Panels C and D).

\section{Self-Perception of Savings Behavior}

In the follow-up survey, we included several questions about personal savings habits and attitudes. In earlier research we found that time-inconsistent women were more likely than timeconsistent women to take up the SEED product, but that no such differential was found for men. ${ }^{8}$ Here we examine whether there are heterogeneous treatment effects on savings attitudes and practices for men versus women and time-inconsistent versus time-consistent clients. Table 6 presents the results on four outcomes using an ordered probit specification. For each outcome, the respondent was asked whether they strongly agree, agree, are neutral, disagree or strongly

\footnotetext{
${ }^{8}$ Individuals defined as present-biased time-inconsistent when in hypothetical time preference questions in the survey, they revealed a higher discount rate for tradeoffs between now and 30 days than tradeoffs between 6 months and 7 months.
} 
disagree with a specific statement. First, we ask about savings practices: (1) (Columns 1 and 2) “Although my income is low, I am a disciplined saver”, (2) (Columns 3 and 4) "I never save”, and (3) (Columns 5 and 6) "When I have a little cash, I spend it rather than save it." We find no aggregate effect, although we do find that time-inconsistent women who were offered the SEED account report being more likely to be a disciplined saver, less likely to never save, and less likely to report spending rather than saving extra cash. This indicates that at least in their perception, the SEED account helped them overcome their self-control problem and led to improved savings practices (in earlier research, we do not find that the time-inconsistent women actually save more than the time-consistent women).

The final statement (Columns 7 and 8) is "I often find that I regret spending money. I wish that when I had cash, I was better disciplined and saved it rather than spent it.” Being assigned to treatment makes individuals more likely to report feeling regret over their spending and savings decisions. ${ }^{9}$ Note that only $28 \%$ of those offered SEED took up, and of those only about one-third regularly used the account. ${ }^{10}$ Hence it follows that although SEED helped $10 \%$ of the treatment group save more (and generate an overall positive intent-to-treat effect), the mere offer of the SEED account generated, on average, a feeling of remorse. Perhaps those who did not take up and use felt remorse, and those who did take up and use did not feel remorse, but the average effect is an increase in remorse because of the relative size of these two groups. Perhaps a second marketing would have been more successful than the first, if the first offer made individuals more aware of their inability to save as much as they would like.

\section{Impact on Aggregate Savings or Debt Levels}

Table 7 reports the intent-to-treat (ITT) effect of random assignment to the treatment group across all asset and financial savings categories from the one-year follow-up survey. Coefficients

\footnotetext{
${ }^{9}$ Interestingly, agreeing with this statement is also correlated with being time-inconsistent when answering hypothetical time preference questions.

${ }^{10}$ Appendix Table 1 shows that about half of the individuals who have not withdrawn their funds did not due to because of a failure to use the account (the modal response is "could not save", with 43 individuals).
} 
on the treatment assignment can be interpreted as the average savings increase from being offered the commitment product. By comparing the ITT impact on financial savings held at the Green Bank against the impact on savings held in assets and other informal and formal financial savings vehicles, we are able to test whether the savings impact of the commitment product reported in Ashraf, Karlan and Yin (2006) represents increased savings or crowd-out of savings held in other vehicles.

We find that after 12 months treatment has no effect on the level of total assets (Column 4) and financial savings reported in the survey (Column 5), thus indicating that the increase in savings at the Green Bank is not due to crowd-out of savings from other savings vehicles into the commitment product. However, we draw this conclusion with caution, as the estimated treatment impact for household savings is not precisely estimated.

We separate household savings into Green Bank total savings, Green Bank non-SEED savings, informal savings, and self-reported savings held at non-Green Bank financial institutions. Column 7 shows that the imprecision comes primarily from self-reported savings held at other financial institutions. ${ }^{11}$ We find no evidence of substitution across assets or savings held at home or in informal savings institutions (Column 6), and no substitution across accounts held within the Green Bank (Column 3), where crowd-out may be most likely to occur. Finally, columns 8 and 9 show that assignment to the commitment treatment group affected neither the probability of borrowing money, nor the size of debt held by the household.

\section{Long-Term Impact}

\footnotetext{
${ }^{11}$ The large standard error may be due to unsystematic measurement error in self-reported savings levels, or to wide heterogeneity in the degree of savings crowd-out due to the treatment. We lack institutional data for savings held at non-Green Bank institutions to compare self-reported savings to actual savings levels. However, for Green Bank savings, we have both institutional data and self-reported savings. We regress true institutional savings on self-reported savings, and find that the residuals of the regression are not predicted by assignment to treatment group. Results not shown, but available upon request. Therefore, the imprecision in the estimated impact in column 7 is likely the outcome of unsystematic measurement error in self-reported savings.
} 
The impact did not sustain itself after the first year. After 12 months the product led to an 81\% increase in savings (404 pesos, Table 7 Column 1) held at the bank, whereas after 32 months the increase is albeit positive, but only 33\% (164 pesos, Table 7 Column 2) and no longer statistically significant. ${ }^{12}$ We posit four explanations for the lack of continued increase in savings balances. First, use of the accounts was heterogeneous. Many opened the accounts but never returned to continue depositing. Others opened, deposited frequently, reached their goal, and then withdrew the funds. Hence the puzzle is why the high-use individuals did not use the account again for further goals beyond the first year, since it seems to have worked initially for them. ${ }^{13}$ Perhaps the account worked but requires a proactive bank to help set the goal and establish the account (again) as a mechanism to help achieve that goal. Only about one-quarter of the individuals that opened the accounts made deposits beyond the initial deposit, and only 26 (13\%) individuals used the funds for their originally stated goal (Appendix Table 1). Thus about half of those who actively used the account reached their goal, withdrew their savings, and used the funds as originally intended.

Second, going back to the theory behind the preference for commitment, perhaps the present self wins in the long run-if the commitment can be undone in the future. The SEED account caused a deviation from a low savings equilibrium, and gradually, individuals found ways to return back to the equilibrium they were in before. This is similar to saying that habits are hard to change. The Green Bank engaged in no activity to continually promote the SEED account. If in each moment in time a client has a certain probability, less than one, of continuing to use the account, then clearly usage in aggregate will diminish over time. Perhaps the product would have been more successful in the long run with continued marketing and promotion, by asking clients for an active decision to renew (Choi, Laibson, Madrian and Metrick 2005), or through

\footnotetext{
${ }^{12}$ We also find no results in a quartile regression. Results are not shown in the table but available upon request.

${ }^{13}$ We do not have access to withdrawal data in order to examine the impact on flow. We only have access to balances.
} 
interventions that automatically defaulted clients into depositing into the account. If, on the other hand, the motivation was familial or spousal control, not self-control, a similar argument holds: over the long run, the other family members took other steps in order to exert back control of loose change and savings decisions. There is some qualitative evidence that this type of pressure occurred for some of the women who were SEED clients. ${ }^{14}$ From these qualitative interviews with SEED clients, it appears that some women who desired the commitment feature of the SEED account had husbands who did not want to have any household funds tied up. This is consistent with our earlier finding that time-inconsistent women were more likely to take up the product, but suggests that for these women commitment cannot always be maintained. Similarly, although husbands report in surveys that they prefer to hand over the money to their wives to manage, in experiments with their spouses husbands instead kept money for themselves (Ashraf 2006).

Third, individuals may have learned from this experience that commitment does work for them but then found other commitment vehicles that are more beneficial (e.g., fixed deposits). Although we cannot rule this out in general, we do not find an increase in overall bank savings, which includes fixed deposits. Fixed deposits are perhaps a good alternative commitment device since they provide a higher interest rate (although the minimum account opening balance may preclude most people from opening such an account). Regardless, there are other vehicles outside of the Green Bank other than fixed deposits, so this test clearly is not dispositive of this explanation.

Fourth, impressionable individuals may have signed up for the SEED account believing it could help them (perhaps in part because they trust the Green Bank of Caraga). In the short run, they saved more. In the long run, they found it did not help them, and they stopped using it. This suggests that the one-year positive impact on savings was actually sub-optimal, that individuals saved more than they ideally would. Although insufficiently conclusive to rule out this

\footnotetext{
${ }^{14}$ One woman who was not able to reach her goal complained that her "husband would not let her save; he said they needed to be able to get the money." Another woman said she "always fought with [her] husband about not being able to withdraw the money in an emergency."
} 
possibility, the result on regret discussed above suggests this is not the explanation: those offered SEED were more likely to report that they "regret spending, and wish they saved more." If after one year individuals found they saved more than they really wanted to, we should have seen a negative, not positive, impact on this question.

\section{Conclusion}

Microfinance has often been argued to improve the bargaining position of women by relaxing their credit constraints and giving them more power over household resources (Hashemi, Schuler and Riley 1996; Kabeer 1999). Even when husbands appropriate their wives' loans, as is common, microcredit is thought to empower women in household decision making processes (Mizan 1993). Policymakers frequently cite these arguments as a key motivation for targeting microfinance and microsavings interventions to women. On the other side, some have argued that microfinance usage and the subsequent need to repay (e.g., in order to protect her reputation amongst her peers) may subjugate women to the power of their spouses, hence potentially increasing domestic violence (Rahman 1999). Evidence (albeit weak) points both ways, and naturally may depend largely on the region-specific economic and social setting. ${ }^{15}$ The effects of microcredit and, more generally, microfinance, which includes savings and/or insurance products, on female empowerment remain unclear, in large part because studies of it tend to suffer from a pronounced selection bias in the type of women who access microcredit (Pitt, Khandker and Cartwright 2003).

Using a randomized control methodology, we evaluate the impact of a commitment microsavings account. First, we find that the commitment product positively impacts both household decision making power (i.e., the household is more likely to buy female-oriented durables) as well as self-perception of savings behavior (time-inconsistent females report being more disciplined savers). Second, we find no evidence of crowd-out of other savings held at the same

\footnotetext{
${ }^{15}$ See Chapter 7 of Armendariz de Aghion and Morduch (2005) for more discussion on this.
} 
financial institution or elsewhere, although the latter is imprecisely measured. Third, we find that the strong (81\%) impact on savings that was observed after 12 months diminishes to 33\% after 32 months.

The diminished long-term impact opens several paths for further research. We posited several reasons, some positive and some negative, why the impact was observed after one year but not after two and a half. Would continued contact from the bank be sufficient to increase the long-term usage of the commitment savings account? Did individuals learn to compensate in other facets of their life, hence negating the benefits of the commitment savings product? Did individuals "learn" that commitment savings products do not work, or instead did individuals not get the reinforcement needed to change long term habits? Experiments that continue to follow up with individuals to reinforce usage, and experiments that cross-sell (perhaps from other institutions) similar or competing commitment products could help separate these stories.

The impact on household decision making suggests another line of experimentation that may also shed insight into the diminished impact. Perhaps the lack of long-term usage was a consequence of the shift in household decision making; it is possible that men became aware of the loss of power and adjusted in order to gain power back. Examining the effect of credit and/or savings products that are deliberately shared versus those that are individualized would help answer whether the change in household decision making can be sustained. Again, we could help answer these questions by following the study for a longer time period and by testing alternative methods of continued marketing and promotion of the product.

Through continued experimentation in this and other settings, we can learn more about how savings product design can help individuals fulfill their savings plans, whether savings product designs alter savings plans, and how these impacts on household decision making affect the efficacy of different savings products. The results here suggest that design features appeal to those with self-control, and have a positive impact on spousal control. These are not contradictory findings, but rather point out that a simple design feature such as a restriction on 
withdrawals can benefit both those in search of self control devices as well as those who desire to have more decision making power in the household. 


\section{References}

Anderson, S. and J.-M. Baland (2002). "The Economics of Roscas and Intra-household Resource Allocation." Quarterly Journal of Economics 117(3): 963-995.

Armendariz de Aghion, B. and J. Morduch (2005). The Economics of Microfinance, MIT Press.

Ashraf, N. (2006). Spousal Control and Intra-Household Decision Making: An Experimental Study in the Philippines, working paper.

Ashraf, N., D. Karlan and W. Yin (2006). "Tying Odysseus to the Mast: Evidence from a Commitment Savings Product in the Philippines." Quarterly Journal of Economics 121(2): 673-697.

Benartzi, S. and R. Thaler (2004). "Save More Tomorrow: Using Behavioral Economics to Increase Employee Saving." Journal of Political Economy 112: S164-S187.

Bernheim, D. B., D. Ray and S. Yeltekin (1999). "Self-Control, Saving, and the Low Asset Trap." manuscript.

Choi, J., D. Laibson, B. C. Madrian and A. Metrick (2005). "Optimal Defaults and Active Decisions." NBER Working Paper No. W11074.

Duflo, E. (2003). "Grandmothers and Granddaughters: Old Age Pension and IntraHousehold Allocation in South Africa." World Bank Economic Review 42: 1-25.

Duflo, E., W. Gale, J. Liebman, P. Orszag and E. Saez (2006). "Saving Incentives for Low- and Middle-Income Families: Evidence from a Field Experiment with H\&R Block." Quarterly Journal of Economics forthcoming.

Feldstein, M. (1974). "Social security, induced retirement and aggregate capital accumulation." Journal of Political Economy 82: 905-926.

Feldstein, M. (1982). "Social security and private saving: reply." Journal of Political Economy 90: 630-642.

Feldstein, M. (1996). "Social security and savings: new time series evidence." National Tax Journal 49: 151-164.

Fudenberg, D. and D. Levine (2005). "A Dual Self Model of Impulse Control." working paper.

Gugerty, M. K. (2006). "You Can't Save Alone: Testing Theories of Rotating Savings and Credit Organizations." Economic Development and Cultural Change forthcoming.

Gul, F. and W. Pesendorfer (2001). "Temptation and Self-Control." Econometrica 69(6): 1403-1436.

Gul, F. and W. Pesendorfer (2004). "Self-Control and the Theory of Consumption." Econometrica 72(1): 119-158.

Hashemi, S., S. R. Schuler and A. P. Riley (1996). "Rural Credit Programs and Women's Empowerment in Bangladesh." World Development 24(4): 635-53.

Hoddinott, J. and L. Haddad (1995). "Does Female Income Share Influence Household Expenditures? Evidence from Côte d'Ivoire." Oxford Bulletin of Economics and Statistics 57: 77-96. 
Kabeer, N. (1999). "Conflicts Over Credit: Re-Evaluating the Empowerment Potential of Loans to Women in Rural Bangladesh." World Development 29.

Kremer, M. and E. A. Miguel (2004). "The Illusion of Sustainability." Center for International and Development Economics Research Paper C05-141.

Laibson, D. (1997). "Golden Eggs and Hyperbolic Discounting." Quarterly Journal of Economics 112(2): 443-477.

Mizan, A. (1993). Women's Decision Making Power in Rural Bangladesh: A Study of the Grameen Bank. The Grameen Bank: Povery Relief in Bangladesh. A. Wahid. Boulder, Westview: 97-126.

O'Donoghue, T. and M. Rabin (1999). "Doing it Now or Doing it Later." The American Economic Review 89(1): 103-121.

Pitt, M. M., S. R. Khandker and J. Cartwright (2003). "Does Micro-Credit Empower Women? Evidence from Bangladesh." World Bank Policy Research Working Paper No. 2998.

Rahman, A. (1999). "Microcredit Initiatives for Equitable and Sustainable Development Who Pays?" World Development 27(1).

Rangel, M. (2005). "Alimony Rights and Intrahousehold Allocation of Resources: Evidence from Brazil." Harris School Working Paper Series 05.5.

Thomas, D. (1990). "Intra-household Resource Allocation: An Inferential Approach." Journal of Human Resources 25: 635-664.

Thomas, D. (1994). "Like Father, Like Son or Like Mother, Like Daughter: Parental Education and Child Health." Journal of Human Resources 24: 950-989.

World Bank (2001). Engendering Development: Through Gender Equality in Rights, Resources and Voice. A World Bank Policy Research Report. Washington, DC and New York, World Bank and Oxford University Press. 
Table 1: Summary Statistics

\begin{tabular}{|c|c|c|c|c|c|}
\hline & $\begin{array}{l}\text { All } \\
\text { (1) }\end{array}$ & $\begin{array}{l}\text { Control } \\
\text { (2) }\end{array}$ & $\begin{array}{c}\text { Treatment } \\
\text { (3) }\end{array}$ & $\begin{array}{l}\text { Marketing } \\
\text { (4) }\end{array}$ & $\begin{array}{c}\text { t-statistics } \\
\text { (5) }\end{array}$ \\
\hline Total & 3,152 & 809 & 1,568 & 775 & \\
\hline Completed baseline survey & 1777 & 469 & 842 & 465 & \\
\hline Completed follow-up survey & 1,629 & 428 & 771 & 430 & \\
\hline \multicolumn{6}{|l|}{ Baseline } \\
\hline Female, proportion & 0.595 & 0.624 & 0.601 & 0.558 & 0.693 \\
\hline Married, proportion & 0.773 & 0.806 & 0.767 & 0.753 & 0.526 \\
\hline Good health, baseline & 0.532 & 0.519 & 0.555 & 0.502 & 0.052 \\
\hline Total savings at Green Bank, MIS & $\begin{array}{c}814.438 \\
(116.501)\end{array}$ & $\begin{array}{c}626.131 \\
(135.009)\end{array}$ & $\begin{array}{c}982.574 \\
(228.033)\end{array}$ & $\begin{array}{l}700.397 \\
(97.404)\end{array}$ & 0.423 \\
\hline Total household savings & $\begin{array}{r}7608.248 \\
(707.948)\end{array}$ & $\begin{array}{c}7304.373 \\
(1224.379)\end{array}$ & $\begin{array}{r}7836.063 \\
(949.195)\end{array}$ & $\begin{array}{c}7502.232 \\
(1679.325)\end{array}$ & 0.760 \\
\hline
\end{tabular}

Standard errors reported in the parentheses. 
Table 2: Impact on Household Decision Making Power

OLS

Sample Framework: Those whose spouses are living in the same house

\begin{tabular}{|c|c|c|c|}
\hline & $\begin{array}{l}\text { All } \\
(1)\end{array}$ & $\begin{array}{l}\text { Decision-making power } \\
\text { below median in baseline } \\
(2)\end{array}$ & $\begin{array}{c}\text { Decision-making power } \\
\text { above median in baseline } \\
\text { (3) }\end{array}$ \\
\hline \multicolumn{4}{|l|}{ Panel A: Female } \\
\hline \multirow[t]{2}{*}{ Treatment } & $0.513^{* *}$ & $0.779 * * *$ & 0.252 \\
\hline & $(0.203)$ & $(0.282)$ & $(0.295)$ \\
\hline \multirow[t]{2}{*}{ Marketing } & 0.182 & 0.209 & 0.193 \\
\hline & $(0.248)$ & $(0.348)$ & $(0.346)$ \\
\hline \multirow[t]{2}{*}{ Household decision making power, baseline } & $0.268 * * *$ & $0.239 * * *$ & $0.233^{* * *}$ \\
\hline & $(0.028)$ & $(0.062)$ & $(0.067)$ \\
\hline \multirow[t]{2}{*}{ Constant } & $7.172^{* * *}$ & $7.241 * * *$ & $7.852 * * *$ \\
\hline & $(0.357)$ & $(0.587)$ & $(0.967)$ \\
\hline Observations & 642 & 330 & 312 \\
\hline R-squared & 0.16 & 0.08 & 0.04 \\
\hline \multicolumn{4}{|l|}{ Panel B: Male } \\
\hline \multirow[t]{2}{*}{ Treatment } & 0.007 & 0.179 & -0.282 \\
\hline & $(0.266)$ & $(0.322)$ & $(0.451)$ \\
\hline \multirow[t]{2}{*}{ Marketing } & 0.150 & 0.440 & -0.281 \\
\hline & $(0.288)$ & $(0.355)$ & $(0.487)$ \\
\hline \multirow[t]{2}{*}{ Household decision making power, baseline } & $0.198 * * *$ & $0.227 * * *$ & 0.114 \\
\hline & $(0.029)$ & $(0.058)$ & $(0.088)$ \\
\hline \multirow[t]{2}{*}{ Constant } & $7.138 * * *$ & $6.747 * * *$ & $8.572 * * *$ \\
\hline & $(0.349)$ & $(0.500)$ & $(1.272)$ \\
\hline Observations & 541 & 304 & 237 \\
\hline R-squared & 0.09 & 0.06 & 0.01 \\
\hline \multicolumn{4}{|c|}{$\begin{array}{l}\text { Robust standard errors in parentheses, } * \text { significant at } 10 \% \text {; } * * \text { significant at } 5 \% \text {; } * * \text { significant at } 1 \% \text {. Dependent Variable: Index o } \\
\text { household decision-making power on what to buy at the market, expensive purchases, giving assistance to family members, family } \\
\text { purchases, recreational use of the money, personal use of the money, number of children, schooling of children, and use of family planning } \\
\text { The value for each item takes zero if the decision making is done by spouse, one if the decision making is done by the couple, and two i } \\
\text { decision making is done by the respondent, and the index is the sum of the value for all the items. }\end{array}$} \\
\hline
\end{tabular}


Table 3: Impact on household decision makring

Sample Framework: Women whose spouses are living in the same house

\begin{tabular}{|c|c|c|c|c|c|c|c|c|c|c|}
\hline Dependent Variable: & $\begin{array}{l}\text { Decision- } \\
\text { making power } \\
\text { index }\end{array}$ & \multirow{2}{*}{$\begin{array}{l}\text { What to buy } \\
\text { in market } \\
\text { Ordered } \\
\text { Probit } \\
\text { (2) }\end{array}$} & \multirow{2}{*}{$\begin{array}{c}\text { Expensive } \\
\text { purchases } \\
\text { Ordered } \\
\text { Probit } \\
\text { (3) } \\
\end{array}$} & \multirow{2}{*}{$\begin{array}{l}\text { Number of } \\
\text { children } \\
\text { Ordered } \\
\text { Probit } \\
(4) \\
\end{array}$} & \multirow{2}{*}{$\begin{array}{c}\text { Family } \\
\text { planning } \\
\text { Ordered } \\
\text { Probit } \\
(5) \\
\end{array}$} & \multirow{2}{*}{$\begin{array}{c}\text { Assist family } \\
\text { members } \\
\text { Ordered } \\
\text { Probit } \\
(6) \\
\end{array}$} & \multirow{2}{*}{$\begin{array}{c}\text { Personal use } \\
\text { Ordered } \\
\text { Probit } \\
\text { (7) } \\
\end{array}$} & \multirow{2}{*}{$\begin{array}{l}\text { Recreation } \\
\text { Ordered } \\
\text { Probit } \\
\text { (8) } \\
\end{array}$} & \multirow{2}{*}{$\begin{array}{c}\text { Family } \\
\text { purchase } \\
\text { Ordered } \\
\text { Probit } \\
\text { (9) } \\
\end{array}$} & \multirow{2}{*}{$\begin{array}{l}\text { Schooling for } \\
\text { children } \\
\text { Ordered } \\
\text { Probit } \\
(10) \\
\end{array}$} \\
\hline Specification: & $\begin{array}{l}\text { OLS } \\
(1)\end{array}$ & & & & & & & & & \\
\hline \multicolumn{11}{|l|}{ Panel A: Female } \\
\hline Treatment & $\begin{array}{l}0.513^{* *} \\
(0.203)\end{array}$ & $\begin{array}{c}-0.003 \\
(0.117)\end{array}$ & $\begin{array}{l}0.203^{*} \\
(0.109)\end{array}$ & $\begin{array}{l}0.217 * \\
(0.114)\end{array}$ & $\begin{array}{c}0.023 \\
(0.110)\end{array}$ & $\begin{array}{c}0.143 \\
(0.113)\end{array}$ & $\begin{array}{c}0.013 \\
(0.118)\end{array}$ & $\begin{array}{c}0.112 \\
(0.107)\end{array}$ & $\begin{array}{c}0.174 \\
(0.112)\end{array}$ & $\begin{array}{c}0.162 \\
(0.125)\end{array}$ \\
\hline Marketing & $\begin{array}{c}0.182 \\
(0.248)\end{array}$ & $\begin{array}{l}-0.031 \\
(0.135)\end{array}$ & $\begin{array}{c}0.062 \\
(0.129)\end{array}$ & $\begin{array}{c}0.139 \\
(0.137)\end{array}$ & $\begin{array}{l}-0.114 \\
(0.131)\end{array}$ & $\begin{array}{c}0.033 \\
(0.125)\end{array}$ & $\begin{array}{l}-0.129 \\
(0.137)\end{array}$ & $\begin{array}{c}0.054 \\
(0.120)\end{array}$ & $\begin{array}{c}0.097 \\
(0.138)\end{array}$ & $\begin{array}{c}0.199 \\
(0.151)\end{array}$ \\
\hline Constant & $\begin{array}{c}7.172 * * * \\
(0.357)\end{array}$ & & & & & & & & & \\
\hline $\begin{array}{l}\text { Observations } \\
\text { R-squared }\end{array}$ & $\begin{array}{l}642 \\
0.16\end{array}$ & 640 & 641 & 638 & 640 & 641 & 642 & 641 & 640 & 608 \\
\hline \multicolumn{11}{|c|}{$\begin{array}{l}\text { Panel B: Females with household decision making power below median in baseline } \\
\end{array}$} \\
\hline Treatment & $\begin{array}{c}0.779 * * * \\
(0.282)\end{array}$ & $\begin{array}{l}-0.030 \\
(0.160)\end{array}$ & $\begin{array}{c}0.430 * * * \\
(0.158)\end{array}$ & $\begin{array}{c}0.174 \\
(0.162)\end{array}$ & $\begin{array}{c}0.032 \\
(0.160)\end{array}$ & $\begin{array}{l}0.267 * \\
(0.157)\end{array}$ & $\begin{array}{l}0.276^{*} \\
(0.164)\end{array}$ & $\begin{array}{c}0.234 \\
(0.150)\end{array}$ & $\begin{array}{c}0.213 \\
(0.162)\end{array}$ & $\begin{array}{l}-0.065 \\
(0.199)\end{array}$ \\
\hline Marketing & $\begin{array}{c}0.209 \\
(0.348)\end{array}$ & $\begin{array}{l}-0.158 \\
(0.180)\end{array}$ & $\begin{array}{c}0.179 \\
(0.179)\end{array}$ & $\begin{array}{c}0.166 \\
(0.180)\end{array}$ & $\begin{array}{l}-0.187 \\
(0.184)\end{array}$ & $\begin{array}{c}0.279 \\
(0.170)\end{array}$ & $\begin{array}{l}-0.218 \\
(0.179)\end{array}$ & $\begin{array}{l}0.295^{*} \\
(0.168)\end{array}$ & $\begin{array}{c}0.143 \\
(0.187)\end{array}$ & $\begin{array}{l}-0.123 \\
(0.228)\end{array}$ \\
\hline Constant & $\begin{array}{c}7.241 * * * \\
(0.587)\end{array}$ & & & & & & & & & \\
\hline Observations & 330 & 328 & 329 & 329 & 329 & 329 & 330 & 329 & 328 & 306 \\
\hline R-squared & 0.08 & & & & & & & & & \\
\hline \multicolumn{11}{|c|}{ Panel C: Females with household decision making power above median in baseline } \\
\hline Treatment & $\begin{array}{c}0.252 \\
(0.295)\end{array}$ & $\begin{array}{c}0.030 \\
(0.173)\end{array}$ & $\begin{array}{c}0.007 \\
(0.151)\end{array}$ & $\begin{array}{c}0.297^{*} \\
(0.160)\end{array}$ & $\begin{array}{c}0.013 \\
(0.152)\end{array}$ & $\begin{array}{c}0.038 \\
(0.163)\end{array}$ & $\begin{array}{c}-0.271 \\
(0.174)\end{array}$ & $\begin{array}{c}0.011 \\
(0.153)\end{array}$ & $\begin{array}{c}0.157 \\
(0.158)\end{array}$ & $\begin{array}{l}0.330 * \\
(0.169)\end{array}$ \\
\hline Marketing & $\begin{array}{c}0.193 \\
(0.346)\end{array}$ & $\begin{array}{c}0.162 \\
(0.207)\end{array}$ & $\begin{array}{l}-0.005 \\
(0.189)\end{array}$ & $\begin{array}{c}0.179 \\
(0.210)\end{array}$ & $\begin{array}{l}-0.040 \\
(0.190)\end{array}$ & $\begin{array}{l}-0.189 \\
(0.184)\end{array}$ & $\begin{array}{c}0.110 \\
(0.220)\end{array}$ & $\begin{array}{l}-0.189 \\
(0.173)\end{array}$ & $\begin{array}{c}0.097 \\
(0.202)\end{array}$ & $\begin{array}{l}0.473 * * \\
(0.210)\end{array}$ \\
\hline Constant & $\begin{array}{c}7.852 * * * \\
(0.967)\end{array}$ & & & & & & & & & \\
\hline $\begin{array}{l}\text { Observations } \\
\text { R-squared }\end{array}$ & $\begin{array}{l}312 \\
0.04\end{array}$ & 312 & 312 & 309 & 311 & 312 & 312 & 312 & 312 & 302 \\
\hline
\end{tabular}

Robust standard errors in parentheses, * significant at 10\%; ** significant at 5\%; *** significant at 1\%. All regressions in this table control for the initial household decision making power in the baseline. The value for each item takes zero if the decision making is done by husband, one if the decision making is done by the couple, and two if decision making is done by wife. Column 1 reports the results from Table 5 of the impact on the index of decision making power, which takes the sum of all decision making items. 
Table 4: Impact on consumer durables

Sample Framework: Those whose spouses are living in the same house

\begin{tabular}{|c|c|c|c|c|c|c|c|c|}
\hline & \multicolumn{2}{|c|}{ House repair } & \multicolumn{3}{|c|}{ Female-oriented durables } & \multicolumn{3}{|c|}{ Other durables } \\
\hline & $\begin{array}{c}\text { Binary } \\
\text { (1) }\end{array}$ & $\begin{array}{c}\text { Cost } \\
(2)\end{array}$ & $\begin{array}{c}\text { Binary } \\
\text { (1) }\end{array}$ & $\begin{array}{c}\text { Total number } \\
(2) \\
\end{array}$ & $\begin{array}{c}\text { Cost } \\
(3)\end{array}$ & $\begin{array}{c}\text { Binary } \\
(4)\end{array}$ & $\begin{array}{c}\text { Total number } \\
\text { (5) }\end{array}$ & $\begin{array}{l}\text { Cost } \\
(6)\end{array}$ \\
\hline \multicolumn{9}{|l|}{$\overline{\text { Panel A: All }}$} \\
\hline Treatment & $\begin{array}{c}0.007 \\
(0.033)\end{array}$ & $\begin{array}{c}172.201 \\
(1,611.810)\end{array}$ & $\begin{array}{l}-0.019 \\
(0.032)\end{array}$ & $\begin{array}{c}0.009 \\
(0.062)\end{array}$ & $\begin{array}{c}48.293 \\
(312.882)\end{array}$ & $\begin{array}{l}-0.015 \\
(0.030)\end{array}$ & $\begin{array}{l}-0.006 \\
(0.042)\end{array}$ & $\begin{array}{l}-2,293.060 \\
(1,529.312)\end{array}$ \\
\hline Marketing & $\begin{array}{c}0.018 \\
(0.038)\end{array}$ & $\begin{array}{l}-1,393.116 \\
(1,648.315)\end{array}$ & $\begin{array}{l}-0.035 \\
(0.036)\end{array}$ & $\begin{array}{l}-0.017 \\
(0.072)\end{array}$ & $\begin{array}{c}144.558 \\
(475.376)\end{array}$ & $\begin{array}{l}-0.011 \\
(0.034)\end{array}$ & $\begin{array}{l}-0.024 \\
(0.047)\end{array}$ & $\begin{array}{l}-2,493.613 \\
(1,543.340)\end{array}$ \\
\hline Constant & & $\begin{array}{c}7,615.907 * * * \\
(1,299.894)\end{array}$ & & $\begin{array}{c}0.495 * * * \\
(0.047)\end{array}$ & $\begin{array}{c}1,997.997 * * * \\
(242.252)\end{array}$ & & $\begin{array}{c}0.305^{* * * *} \\
(0.034)\end{array}$ & $\begin{array}{c}6,095.462 * * * \\
(1,344.654)\end{array}$ \\
\hline Observations & 1181 & 1181 & 1183 & 1183 & 1183 & 1183 & 1183 & 1183 \\
\hline R-squared & & 0.00 & & 0.00 & 0.00 & & 0.00 & 0.00 \\
\hline \multicolumn{9}{|l|}{ Panel B: Females } \\
\hline Treatment & $\begin{array}{c}0.026 \\
(0.045)\end{array}$ & $\begin{array}{c}2,758.632 \\
(1,960.731)\end{array}$ & $\begin{array}{l}-0.023 \\
(0.043)\end{array}$ & $\begin{array}{c}0.086 \\
(0.086)\end{array}$ & $\begin{array}{c}504.622 \\
(433.285)\end{array}$ & $\begin{array}{l}-0.002 \\
(0.040)\end{array}$ & $\begin{array}{c}0.050 \\
(0.052)\end{array}$ & $\begin{array}{l}-2,146.550 \\
(2,340.491)\end{array}$ \\
\hline Marketing & $\begin{array}{c}0.020 \\
(0.053)\end{array}$ & $\begin{array}{l}-1,133.261 \\
(1,875.305)\end{array}$ & $\begin{array}{l}-0.023 \\
(0.051)\end{array}$ & $\begin{array}{c}0.038 \\
(0.104)\end{array}$ & $\begin{array}{c}-56.553 \\
(508.971)\end{array}$ & $\begin{array}{c}0.029 \\
(0.048)\end{array}$ & $\begin{array}{c}0.043 \\
(0.058)\end{array}$ & $\begin{array}{l}-1,731.438 \\
(2,401.692)\end{array}$ \\
\hline Constant & & $\begin{array}{c}6,761.989 * * * \\
(1,289.453)\end{array}$ & & $\begin{array}{c}0.489 * * * \\
(0.060)\end{array}$ & $\begin{array}{c}1,947.878^{* * *} \\
(297.011)\end{array}$ & & $\begin{array}{c}0.261 * * * \\
(0.036)\end{array}$ & $\begin{array}{c}6,230.154 * * * \\
(2,032.658)\end{array}$ \\
\hline Observations & 641 & 641 & 642 & 642 & 642 & 642 & 642 & 642 \\
\hline R-squared & & 0.01 & & 0.00 & 0.00 & & 0.00 & 0.00 \\
\hline \multicolumn{9}{|l|}{ Panel C: Males } \\
\hline Treatment & $\begin{array}{l}-0.016 \\
(0.051)\end{array}$ & $\begin{array}{c}-3,137.328 \\
(2,759.733)\end{array}$ & $\begin{array}{l}-0.012 \\
(0.049)\end{array}$ & $\begin{array}{l}-0.086 \\
(0.090)\end{array}$ & $\begin{array}{l}-519.682 \\
(456.142)\end{array}$ & $\begin{array}{l}-0.032 \\
(0.044)\end{array}$ & $\begin{array}{l}-0.080 \\
(0.071)\end{array}$ & $\begin{array}{l}-2,453.800 \\
(1,739.883)\end{array}$ \\
\hline Marketing & $\begin{array}{c}0.016 \\
(0.056)\end{array}$ & $\begin{array}{l}-2,010.130 \\
(2,942.709)\end{array}$ & $\begin{array}{l}-0.043 \\
(0.052)\end{array}$ & $\begin{array}{l}-0.071 \\
(0.103)\end{array}$ & $\begin{array}{c}315.665 \\
(805.930)\end{array}$ & $\begin{array}{l}-0.055 \\
(0.047)\end{array}$ & $\begin{array}{l}-0.107 \\
(0.077)\end{array}$ & $\begin{array}{l}-3,165.144^{*} \\
(1,764.869)\end{array}$ \\
\hline Constant & & $\begin{array}{c}8,796.324 * * * \\
(2,534.068)\end{array}$ & & $\begin{array}{c}0.504 * * * \\
(0.077)\end{array}$ & $\begin{array}{c}2,066.774 * * * \\
(406.126)\end{array}$ & & $\begin{array}{c}0.365^{* * * *} \\
(0.062)\end{array}$ & $\begin{array}{c}5,910.628 * * * \\
(1,555.118)\end{array}$ \\
\hline Observations & 540 & 540 & 541 & 541 & 541 & 541 & 541 & 541 \\
\hline R-squared & & 0.00 & & 0.00 & 0.00 & & 0.00 & 0.01 \\
\hline
\end{tabular}

Robust standard errors in parentheses, * significant at $10 \%$;* significant at $5 \%$; *** significant at $1 \%$. Female-oriented durables consist of washing machines, sewing machines, electric iron, kitchen appliances, air conditioners, fans, and stoves. Other durables include vehicles, motorcycles, and entertainment items (i.e. CD players, TV, and radio ). 
Table 5: Impact on consumer durables

Sample Framework: Those whose spouses are living in the same house

\begin{tabular}{|c|c|c|c|c|c|c|}
\hline & \multicolumn{2}{|c|}{ House repair } & \multicolumn{2}{|c|}{ Female-Oriented Durables } & \multicolumn{2}{|c|}{ Other Durables } \\
\hline & $\begin{array}{c}\text { Binary } \\
(1)\end{array}$ & $\begin{array}{l}\text { Cost } \\
(2) \\
\end{array}$ & $\begin{array}{c}\text { Total number } \\
\text { (3) } \\
\end{array}$ & $\begin{array}{l}\text { Cost } \\
(4)\end{array}$ & $\begin{array}{c}\text { Total number } \\
\text { (5) }\end{array}$ & $\begin{array}{l}\text { Cost } \\
(6)\end{array}$ \\
\hline \multicolumn{7}{|c|}{ 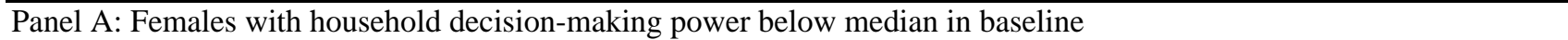 } \\
\hline Treatment & $\begin{array}{l}-0.033 \\
(0.062)\end{array}$ & $\begin{array}{c}857.273 \\
(2,623.079)\end{array}$ & $\begin{array}{l}0.214^{*} \\
(0.110)\end{array}$ & $\begin{array}{c}1,424.217^{* *} \\
(643.660)\end{array}$ & $\begin{array}{c}0.023 \\
(0.072)\end{array}$ & $\begin{array}{c}-3,628.674 \\
(3,991.801)\end{array}$ \\
\hline Marketing & $\begin{array}{c}0.070 \\
(0.073)\end{array}$ & $\begin{array}{c}-2,725.065 \\
(2,278.069)\end{array}$ & $\begin{array}{c}0.115 \\
(0.139)\end{array}$ & $\begin{array}{c}521.969 \\
(769.590)\end{array}$ & $\begin{array}{c}0.066 \\
(0.086)\end{array}$ & $\begin{array}{c}-3,598.015 \\
(3,629.791)\end{array}$ \\
\hline Constant & & $\begin{array}{c}6,683.516 * * * \\
(2,015.289)\end{array}$ & $\begin{array}{c}0.385^{* * * *} \\
(0.068)\end{array}$ & $\begin{array}{c}1,545.604^{* * *} \\
(353.341)\end{array}$ & $\begin{array}{c}0.264^{* * * *} \\
(0.056)\end{array}$ & $\begin{array}{c}7,772.527 * * \\
(3,436.760)\end{array}$ \\
\hline Observations & 330 & 330 & 330 & 330 & 330 & 330 \\
\hline R-squared & & 0.01 & 0.01 & 0.01 & 0.00 & 0.00 \\
\hline \multicolumn{7}{|c|}{ Panel B: Females with household decision-making power above median in baseline } \\
\hline Treatment & $\begin{array}{c}0.088 \\
(0.064)\end{array}$ & $\begin{array}{c}4,771.143 \\
(2,959.613)\end{array}$ & $\begin{array}{l}-0.037 \\
(0.131)\end{array}$ & $\begin{array}{l}-417.865 \\
(562.495)\end{array}$ & $\begin{array}{c}0.078 \\
(0.076)\end{array}$ & $\begin{array}{c}-763.065 \\
(2,505.552)\end{array}$ \\
\hline Marketing & $\begin{array}{l}-0.039 \\
(0.079)\end{array}$ & $\begin{array}{c}900.238 \\
(3,211.015)\end{array}$ & $\begin{array}{l}-0.027 \\
(0.151)\end{array}$ & $\begin{array}{l}-652.920 \\
(600.110)\end{array}$ & $\begin{array}{c}0.015 \\
(0.079)\end{array}$ & $\begin{array}{c}118.330 \\
(3,363.112)\end{array}$ \\
\hline Constant & & $\begin{array}{c}6,835.608 * * * \\
(1,643.302)\end{array}$ & $\begin{array}{c}0.588^{* * *} \\
(0.097)\end{array}$ & $\begin{array}{c}2,325.268 * * * \\
(469.066)\end{array}$ & $\begin{array}{c}0.258^{* * *} \\
(0.047)\end{array}$ & $\begin{array}{c}4,783.186 * * \\
(2,269.788)\end{array}$ \\
\hline Observations & 311 & 311 & 312 & 312 & 312 & 312 \\
\hline R-squared & & 0.01 & 0.00 & 0.00 & 0.00 & 0.00 \\
\hline \multicolumn{7}{|c|}{ Panel C: Males with household decision-making power below median in baseline } \\
\hline Treatment & $\begin{array}{l}-0.017 \\
(0.065)\end{array}$ & $\begin{array}{l}-4,305.538 \\
(4,185.893)\end{array}$ & $\begin{array}{l}-0.075 \\
(0.119)\end{array}$ & $\begin{array}{l}-622.598 \\
(609.056)\end{array}$ & $\begin{array}{l}-0.073 \\
(0.096)\end{array}$ & $\begin{array}{l}-3,304.368 \\
(2,537.356)\end{array}$ \\
\hline Marketing & $\begin{array}{l}-0.054 \\
(0.070)\end{array}$ & $\begin{array}{c}-3,920.212 \\
(4,500.404)\end{array}$ & $\begin{array}{l}-0.004 \\
(0.144)\end{array}$ & $\begin{array}{c}779.900 \\
(1,274.342)\end{array}$ & $\begin{array}{c}-0.194 * * \\
(0.093)\end{array}$ & $\begin{array}{c}-5,195.566^{* *} \\
(2,394.219)\end{array}$ \\
\hline Constant & & $\begin{array}{c}9,787.654 * * \\
(3,988.753)\end{array}$ & $\begin{array}{c}0.469 * * * \\
(0.102)\end{array}$ & $\begin{array}{c}2,031.728^{* * * *} \\
(556.478)\end{array}$ & $\begin{array}{c}0.379 * * * \\
(0.082)\end{array}$ & $\begin{array}{c}6,652.543 * * * \\
(2,334.842)\end{array}$ \\
\hline Observations & 304 & 304 & 304 & 304 & 331 & 304 \\
\hline R-squared & & 0.01 & 0.00 & 0.01 & 0.01 & 0.02 \\
\hline \multicolumn{7}{|c|}{ Panel D: Males with household decision-making power above median in baseline } \\
\hline Treatment & $\begin{array}{l}-0.016 \\
(0.080)\end{array}$ & $\begin{array}{c}-1,461.006 \\
(2,898.849)\end{array}$ & $\begin{array}{l}-0.107 \\
(0.136)\end{array}$ & $\begin{array}{l}-401.616 \\
(683.203)\end{array}$ & $\begin{array}{l}-0.085 \\
(0.105)\end{array}$ & $\begin{array}{c}-1,247.768 \\
(2,157.674)\end{array}$ \\
\hline Marketing & $\begin{array}{c}0.103 \\
(0.089)\end{array}$ & $\begin{array}{c}594.941 \\
(3,073.887)\end{array}$ & $\begin{array}{l}-0.162 \\
(0.147)\end{array}$ & $\begin{array}{l}-269.957 \\
(867.416)\end{array}$ & $\begin{array}{c}0.039 \\
(0.132)\end{array}$ & $\begin{array}{c}-486.051 \\
(2,477.748)\end{array}$ \\
\hline Constant & & $\begin{array}{c}7,336.364^{* * *} \\
(2,207.911)\end{array}$ & $\begin{array}{c}0.554^{* * *} \\
(0.116)\end{array}$ & $\begin{array}{c}2,117.464^{* * * *} \\
(586.932)\end{array}$ & $\begin{array}{c}0.340 * * * \\
(0.093)\end{array}$ & $\begin{array}{c}4,837.500^{* * *} \\
(1,762.265)\end{array}$ \\
\hline Observations & 236 & 236 & 237 & 237 & 210 & 237 \\
\hline R-squared & & 0.00 & 0.01 & 0.00 & 0.01 & 0.00 \\
\hline
\end{tabular}

Robust standard errors in parentheses, * significant at 10\%; ** significant at 5\%; *** significant at $1 \%$. Female-oriented durables consist of washing machines, sewing machines, electric iron, kitchen appliances, air conditioners, fans, and stoves. Other durables include vehicles, motorcycles, and entertainment items (i.e. CD players, TV, and radio ). 
Table 6: Impact on Savings Attitude

Ordered Probit

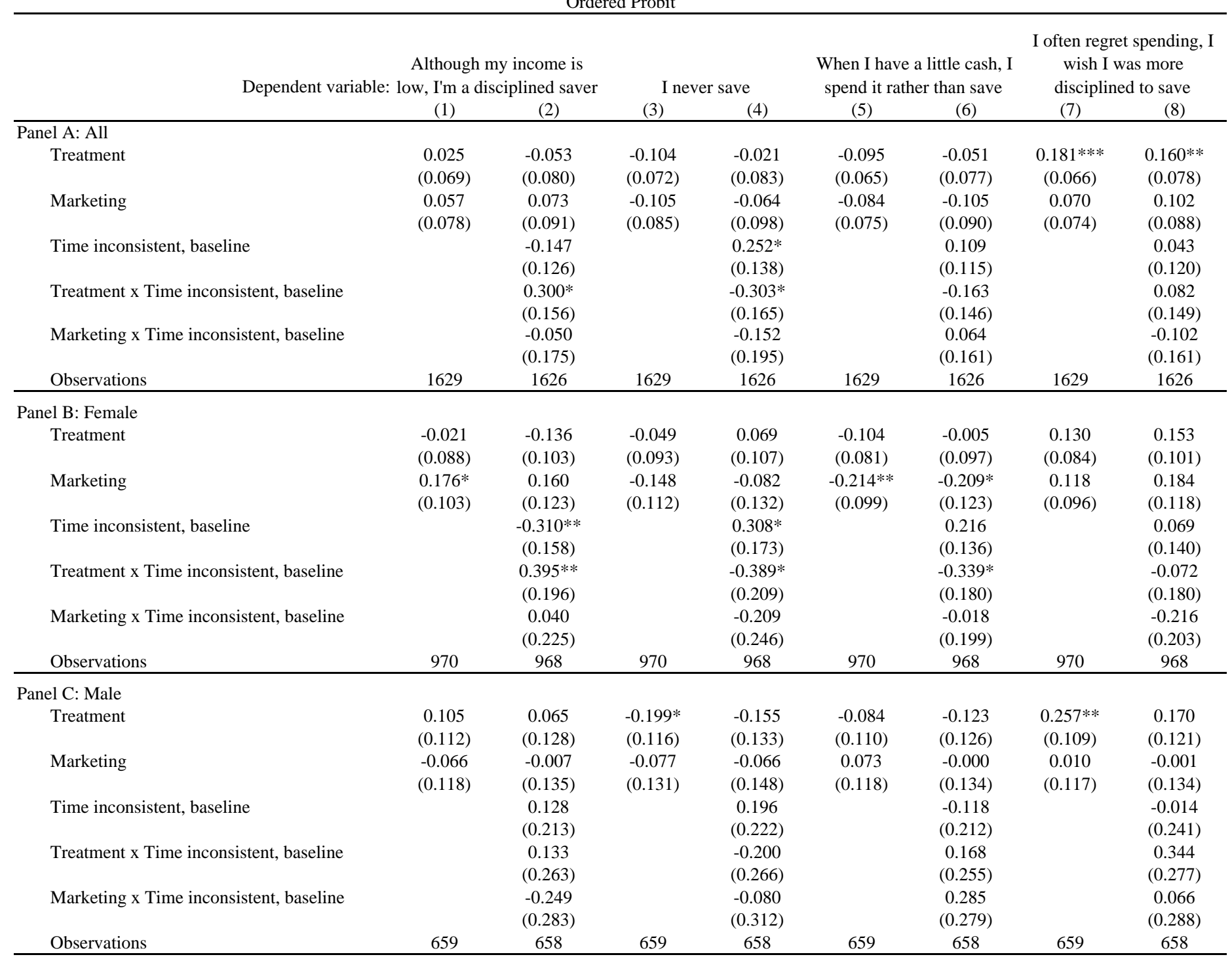

Robust standard errors in parentheses, * significant at $10 \% ; * *$ significant at $5 \%$; *** significant at $1 \%$. Dependent variables are categorical, indicating how strongly the respondent agrees to each statement. The variable equals one if the respondent strongly disagree, two if somewhat disagree, three if neutral, four if somewhat agree, and five if strongly agree. 
Table 7: Impact on Savings

\begin{tabular}{|c|c|c|c|c|c|c|c|c|c|}
\hline \multicolumn{10}{|c|}{ OLS } \\
\hline & $\begin{array}{l}\text { Green Bank savings, } \\
\text { Aug } 04 \text { (12 months) }\end{array}$ & $\begin{array}{c}\text { Green Bank savings, } \\
\text { Apr 06 } \\
\text { (32 months) }\end{array}$ & \begin{tabular}{|c} 
Non-SEED Green \\
Bank savings, Aug 04 \\
(12 months)
\end{tabular} & $\begin{array}{l}\text { Total Assets } \\
\text { (12 months) }\end{array}$ & $\begin{array}{l}\text { Household total } \\
\text { savings } \\
\text { (12 months) }\end{array}$ & $\begin{array}{l}\text { Household informal } \\
\text { savings } \\
\text { (12 months) }\end{array}$ & $\begin{array}{l}\text { Client's own formal } \\
\text { savings } \\
\text { (12 months) }\end{array}$ & $\begin{array}{l}\text { Applied for a Loan } \\
\text { (12 Months) }\end{array}$ & $\begin{array}{l}\text { Total Debt } \\
\text { (12 Months) }\end{array}$ \\
\hline Data Source: & Green Bank & Green Bank & Green Bank & Survey & Survey & Survey & Survey & $\begin{array}{c}\text { Survey } \\
\text { Completed }\end{array}$ & $\begin{array}{c}\text { Survey } \\
\text { Completed }\end{array}$ \\
\hline Sample frame: & $\begin{array}{c}\text { Completed Baseline } \\
(1)\end{array}$ & $\begin{array}{c}\text { Completed Baseline } \\
(2)\end{array}$ & $\begin{array}{c}\text { Completed Baseline } \\
\text { and Followup } \\
\text { (3) }\end{array}$ & $\begin{array}{c}\text { Completed Baseline } \\
\text { and Followup } \\
(4)\end{array}$ & $\begin{array}{c}\text { Completed Baseline } \\
\text { and Followup } \\
\text { (5) }\end{array}$ & $\begin{array}{c}\text { Completed Baseline } \\
\text { and Followup } \\
\text { (6) }\end{array}$ & $\begin{array}{c}\text { Completed Baseline } \\
\text { and Followup } \\
(7) \\
\end{array}$ & $\begin{array}{l}\text { Baseline and } \\
\text { Followup } \\
\text { (8) }\end{array}$ & $\begin{array}{l}\text { Baseline and } \\
\text { Followup } \\
\text { (9) }\end{array}$ \\
\hline Treatment & $\begin{array}{l}404.320^{*} \\
(246.314)\end{array}$ & $\begin{array}{c}163.520 \\
(289.632)\end{array}$ & $\begin{array}{c}-36.162 \\
(244.133)\end{array}$ & $\begin{array}{c}4,994.054 \\
(8,906.509)\end{array}$ & $\begin{array}{c}563.659 \\
(1,536.951)\end{array}$ & $\begin{array}{c}246.797 \\
(274.744)\end{array}$ & $\begin{array}{c}568.355 \\
(1,050.772)\end{array}$ & $\begin{array}{c}0.098 \\
(0.026)\end{array}$ & $\begin{array}{c}1,511.81 \\
(1,870.30)\end{array}$ \\
\hline Marketing & $\begin{array}{l}115.880 \\
(153.847)\end{array}$ & $\begin{array}{l}-145.718 \\
(196.025)\end{array}$ & $\begin{array}{l}-240.604 \\
(230.557)\end{array}$ & $\begin{array}{c}-7,928.332 \\
(8,654.795)\end{array}$ & $\begin{array}{c}573.717 \\
(2,098.007)\end{array}$ & $\begin{array}{l}-199.471 \\
(156.060)\end{array}$ & $\begin{array}{c}1,119.032 \\
(1,585.840)\end{array}$ & $\begin{array}{l}-0.0012 \\
(0.030)\end{array}$ & $\begin{array}{c}-402.22 \\
(2,077.65)\end{array}$ \\
\hline Savings amount in baseline & $\begin{array}{c}0.748^{* * *} \\
(0.162)\end{array}$ & $\begin{array}{c}0.318^{* * *} \\
(0.095)\end{array}$ & $\begin{array}{c}0.662 \\
(0.460)\end{array}$ & & $\begin{array}{c}0.245^{* * *} \\
(0.076)\end{array}$ & $\begin{array}{c}0.027 \\
(0.017)\end{array}$ & $\begin{array}{c}0.147 \\
(0.092)\end{array}$ & & \\
\hline Constant & $\begin{array}{c}199.189 \\
(162.943)\end{array}$ & $\begin{array}{l}437.099 * * \\
(194.859)\end{array}$ & $\begin{array}{c}241.828 \\
(344.842)\end{array}$ & $\begin{array}{c}62,353.800^{* * *} \\
(6,051.946)\end{array}$ & $\begin{array}{c}5,857.283 * * * \\
(1,264.199)\end{array}$ & $\begin{array}{c}591.756 * * * \\
(137.723)\end{array}$ & $\begin{array}{c}3,133.255^{* * *} \\
(752.259)\end{array}$ & $\begin{array}{c}0.748^{* * * *} \\
(0.021)\end{array}$ & $\begin{array}{c}15,815.89 * * * \\
(1,413.86)\end{array}$ \\
\hline Observations & 1777 & 1777 & 1629 & 1629 & 1629 & 1629 & 1629 & 1629 & 1629 \\
\hline R-squared & 0.01 & 0.00 & 0.30 & 0.00 & 0.02 & 0.00 & 0.01 & 0.00 & 0.00 \\
\hline
\end{tabular}

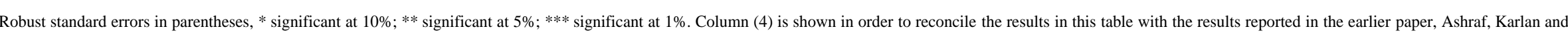

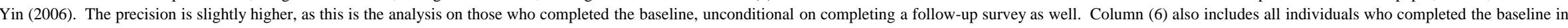
order to provide the best comparison between the earlier reported 12 month results to the 32 month results. 


\section{Appendix Table 1: Qualitative Feedback from SEED Account Holders}

Those that did not withdraw: Reason for not withdrawing

Frequency

Argued with spouse

1

Bad bank service/bank is far

3

Could not save

43

Damaged passbook

1

Destroyed ganansiya box

Did not need money

Did not like terms/low interest

Forgot about it

Inconvenience

Money stolen (7)/lost (1)

Never joined/not a member

Nobody collected

Not interested

Not to term

Rolled over

Total

Those that withdrew: Spent SEED Money on:

Frequency

Fiesta

Children's schooling

Other/did not say

Add to capital of business/sari-sar

Birthday (own, child, grandchild, missus, etc)

Child is giving birth

Children's graduation

Christmas

Contruction of house/repair of kitchen

Everyday needs/necessities/groceries

Medical treatment

Reached time goal (3 months)

Refrigerator

Supplement mothers budget

Total

7

6

4

2

5

1

2

3

2

4

2

1

1

2

42

Spent money on original goal

26

Spent money on different goal from original
14 